\title{
Do Shade-Grown Coffee Plantations Pose a Disease Risk for Wild Birds?
}

Sonia M. Hernandez, ${ }^{1,6}$ Valerie E. Peters, ${ }^{1,9}$ P. Logan Weygandt, ${ }^{2,10}$ Carlos Jimenez, ${ }^{3,8}$ Pedro Villegas, ${ }^{4}$ Barry O’Connor, ${ }^{5,7}$ Michael J. Yabsley, ${ }^{6}$ Maricarmen Garcia, ${ }^{4}$ Sylva M. Riblet, ${ }^{4}$ and C. Ron Carroll ${ }^{1}$

${ }^{1}$ Odum School of Ecology, University of Georgia, Athens, GA 30602

${ }^{2}$ John Hopkins School of Medicine, Baltimore, MD 21205

${ }^{3}$ Escuela de Medicina Veterinaria, Universidad Nacional de Costa Rica, Heredia, Costa Rica

${ }^{4}$ Department of Population Health, Poultry Diagnostic and Research Center, College of Veterinary Medicine, University of Georgia, Athens, GA 30602

${ }^{5}$ Insect Division, Museum of Zoology, University of Michigan, Ann Arbor, MI 48109

${ }^{6}$ Daniel B. Warnell School of Forestry and Natural Resources and the Southeastern Cooperative Wildlife Disease Study, University of Georgia, 180 Green St., Athens, GA 30602

${ }^{7}$ Present address: Department of Ecology and Evolutionary Biology, University of Michigan, Ann Arbor, MI 48109-1079

${ }^{8}$ Present address: Programa de Investigacion en Enfermedades Tropicales, Escuela de Medicina Veterinaria, Universidad Nacional, Heredia 304-3000, Costa Rica

${ }^{9}$ Present address: Department of Zoology, Miami University, Oxford, OH 45056

${ }^{10}$ Present address: $121 \mathrm{~N}$ Chester St., Baltimore, MD 21231

Abstract: Shade-grown coffee plantations are often promoted as a conservation strategy for wild birds. However, these agro-ecosystems are actively managed for food production, which may alter bird behaviors or interactions that could change bird health, compared to natural forest. To examine whether there is a difference between the health parameters of wild birds inhabiting shade-grown coffee plantations and natural forest, we evaluated birds in Costa Rica for (1) their general body condition, (2) antibodies to pathogens, (paramyxovirus and Mycoplasma spp.), and (3) the prevalence and diversity of endo-, ecto-, and hemoparasites. We measured exposure to Mycoplasma spp. and paramyxovirus because these are pathogens that could have been introduced with domestic poultry, one mechanism by which these landscapes could be detrimental to wild birds. We captured 1,561 birds representing 75 species. Although seasonal factors influenced body condition, we did not find bird general body condition to be different. A total of 556 birds of 31 species were tested for antibodies against paramyxovirus-1. Of these, five birds tested positive, four of which were from shade coffee. Out of 461 other tests for pathogens (for antibodies and nucleotide detection), none were positive. Pterolichus obtusus, the feather mite of chickens, was found on 15 birds representing two species and all were from shade-coffee plantations. Larvated eggs of Syngamus trachea, a nematode typically associated with chickens, were found in four birds captured in shade coffee and one captured in forest. For hemoparasites, a total of 1,121 blood smears from 68 bird species were examined, and only one species showed a higher prevalence of infection in shade coffee. Our results indicate that shade-coffee plantations do not pose a significant health risk to forest birds, but at least two groups of pathogens may deserve further attention: Haemoproteus spp. and the diversity and identity of endoparasites.

Keywords: disease, pathogen, wild bird, Costa Rica, shade coffee, conservation

Published online: May 2, 2013

Correspondence to: Sonia M. Hernandez, e-mail: shernz@uga.edu 


\section{INTRODUCTION}

Habitat loss affects $89 \%$ of threatened birds worldwide, a majority of which are impacted due to loss of tropical forests (Hilton-Taylor 2000). In the tropics, the balance between preserving forests and deforestation for human development remains a major challenge. The increased edge effect and smaller habitat patch area that results from habitat fragmentation, compounded with a hostile landscape matrix often composed of large monocultures pose a variety of threats to biodiversity, including (1) promoting biological impoverishment as small populations disappear, (2) creating favorable conditions for the persistence of exotic species, (3) favoring the abundance of generalist species, and (4) potentially creating points of artificial aggregation or concentration of wildlife (Groom 2006). New conservation approaches recognize these landscape scale threats and have emphasized human-dominated landscapes, shifted their focus to ecosystem services, and promoted utilizing innovative financial incentives to support biodiversity (Sanchez-Azofeifa et al. 2007). One such incentive approach is the promotion of shade-grown coffee, by conservation-minded communities who have identified this type of coffee agriculture as both a desirable economic model as well as a surrogate for forested habitat. Shadegrown coffee has been promoted as a means to provide economic support for people while sustaining biodiversity and buffering protected areas (Perfecto and Vandermeer 2008). For example, there is strong evidence that coffee plantations managed under a floristically and structurally diverse forest canopy (henceforth, shade coffee) provide important habitat for diverse avian communities (Moguel and Toledo 1999; Perfecto et al. 1996; Perfecto et al. 2007). Thus, shade-grown coffee may be viewed as a surrogate for forest habitats by maintaining avian communities that in large part reflect those found in large tracts of forest. The benefits to biodiversity from shade-grown coffee systems are well documented and have been summarized in recent reviews (Moguel and Toledo 1999; Perfecto et al. 2004; Philpott and Armbrecht 2006) one of which has outlined the specific benefits of shade market certification to biodiversity (Philpott et al. 2007). Although the percent area of coffee managed under shade trees versus full sun varies greatly among the coffee-producing nations (e.g., $5 \%$ coffee under shade in Brazil to $90 \%$ under shade in Peru), only $\sim 60 \%$ of Latin American coffee farms have remained as shaded systems since the original movement in the 1970s to increase coffee yields via the intensification of farms (i.e., via the removal of shade trees) (Rice and Ward 1996; Jha et al. 2011).

Amidst growing evidence that shade coffee can benefit tropical forest species, a recent critical review cautions against the promotion of shade coffee as a conservation tool for birds, stating that Future research, however, should consider the hypothesis that coffee plantations, as a disturbed habitat, may in fact be undesirable or dangerous for some birds (Rappole et al. 2003, Cohen and Lindell 2004), potentially being a sink habitat for forest bird species or a death trap for dispersers and some migratory visitors (Komar 2006). In this study, we explore this warning, by investigating whether or not shade coffee parcels may pose a risk of pathogen transmission to birds that occupy them because: (1) shade coffee farms are often small, and, therefore, subject to large edge effects, (2) the resource-rich farms promote aggregations of birds at densities that might be higher than what is found in nearby forest fragments, increasing contact rates or reaching threshold population densities for disease outbreaks, and, (3) most important to this study, shade coffee typically harbors flocks of poultry, known to be potential reservoirs for avian pathogens (Hernandez-Divers et al. 2008). In fact, poultry in shadecoffee plantations in this region were found to specifically have a high prevalence of infection with both paramyxovirus and Mycoplasma spp. (Hernandez-Divers et al. 2008). Although a common component of shade coffee systems, flocks of poultry are mostly absent from the more intensified, sun-coffee production systems. This is because shade-coffee plantations are frequently smallholder farms managed as polyculture home gardens, and farmers rely on a variety of agricultural products to be harvested from the garden - with poultry constituting one additional source of nutrition/income. Furthermore, because these poultry flocks are managed, they normally forage strictly inside farm boundaries, and are, therefore, mostly absent from forest systems where they are vulnerable to predation.

The primary objective of this study was to investigate the prevalence/diversity of pathogens and health of wild birds inhabiting shade-grown coffee parcels, comparing these with the same species of birds inhabiting forest fragments. Our study could help answer a critical question about the costs and benefits of shade-grown coffee for wild birds. Do the wild birds that use these habitats show evidence of increased exposure to pathogens and does it matter for individuals or populations-are they less healthy 
than conspecifics living in nearby forest habitat? And more generally, does it provide useful information that would allow us to make intelligent predictions about changes in disease dynamics in sustainable agricultural land in the tropics?

Generalities about pathogens are often not valid, thus we further subdivided our hypothesis into relevant pathogen-specific predictions. In comparison with birds in forest patches, we predict that birds in shade-grown coffee will have higher disease prevalence of (1) directly transmitted pathogens, such as paramyxovirus and Mycoplasma spp., potentially as a result of artificial aggregation and contact with domestic chickens Gallus domesticus; and (2) vectorborne diseases, such as the hemoparasite, Hemoproteus spp., potentially as a result of deforestation-related changes to vector population biology. In addition, both prevalence of infection and diversity of endo- and ectoparasites will be higher in birds living in coffee plantations due to artificial aggregation or contact with domestic chickens and, finally, subjective measures of avian body condition will be higher in birds dwelling in forest fragments due in part to greater disease prevalence in coffee farms. This study follows our previous investigation that established the pathogen prevalence of domestic chickens in this region, and its relevance to songbirds (Hernandez-Divers et al. 2008).

\section{Materials and Methods}

\section{Study Site}

This study took place in the San Luis valley, located in the Northwest region of Costa Rica, $\sim 7 \mathrm{~km}$ from the town of Santa Elena in the Monteverde region, in the province of Guanacaste. The University of Georgia (UGA) San Luis Research Station $\left(10^{\circ} 16^{\prime} \mathrm{N}, 84^{\circ} 47^{\prime} \mathrm{W}\right)$ served as the base for all laboratory processing. Seven study sites, located within the pre-montane life zone, at $\sim 1,100$ m elevation, were chosen. Four shade-grown coffee plantation sites (from here forward, Coffee 1-4) were within Finca La Bella, a cooperative farm established by conservationists to provide sustainable agricultural alternatives to the people in San Luis. All coffee plantations included in our study were approximately 1 ha and shared the following management practices: low chemical input from fertilizers, no pesticide use, high diversity of shade trees (19-23 species ha ${ }^{-1}$ ), a high shade cover $($ mean $=68$, range $=62-80 \%)$, and mechanical elimination of weeds (by machete). Three forest sites (approximately 2 ha each; Forest 1-3) were embedded within forest fragments of old secondary growth ( $\sim 75$ years), two within the (UGA) property and one within Finca La Bella. The minimum distance between proximate sites was $250 \mathrm{~m}$ (Figure 1).

\section{Avian Capture and Handling}

Birds were captured in study sites using mist nets, following the standard methodology described in Bibby et al. (2000). Mist netting was conducted from July 2005 to January 2008, across eight sampling periods (Table 1), and included a total of 11,180 mist-net hours (calculated as the number of open nets times the number of hours). Eight to twelve mist nets were placed in each sampled site during a sampling period, and each sampling period lasted from 2 to 3 months. Placement locations of nets within sites were selected to maximize bird capture rates. All mist nets had 38-mm mesh, and were $2 \mathrm{~m}$ high $\times$ either 9 or $12 \mathrm{~m}$ long. The specific dates of sampling periods were selected to produce data representative of both seasons (wet vs. dry) and avian reproductive activity (breeding vs. non-breeding periods).

All captured birds were extracted from the nets, and placed in individual, disposable paper bags. Birds were processed immediately to minimize holding time. In most cases, birds were released within 20 min of extraction from the nets, and released near the point of capture. Birds were banded with site-specific numbered and color-coded plastic leg bands. Our mark-recapture study data in combination with another bird mark-recapture study conducted in the

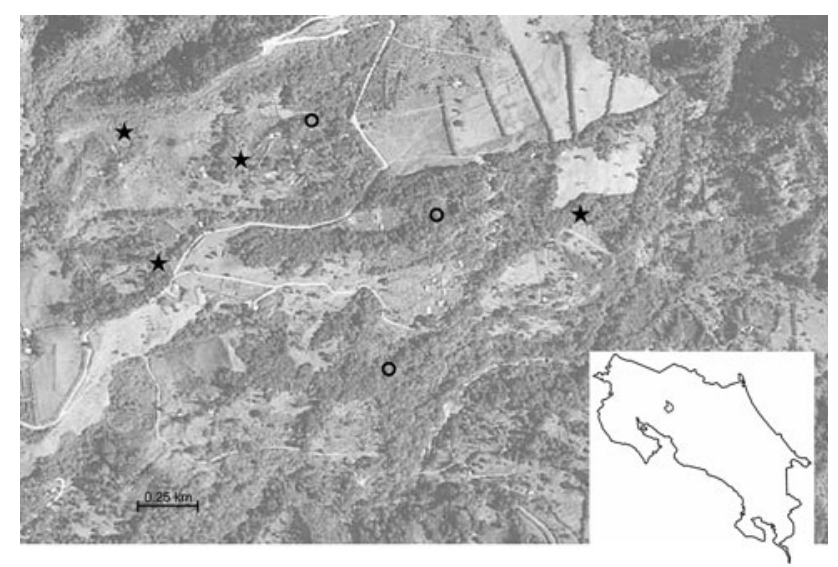

Figure 1. Study sites in San Luis de Monteverde, a region in Northwestern Costa Rica, outlined in black within the inserted map of Costa Rica. Stars denote shade-grown coffee plantations and open circles denote forest sites. 
Table 1. Eight Sampling Periods Were Realized From 2005-2008 Representing a Variety of Climatic and Reproductive Seasons.

\begin{tabular}{lllll}
\hline Sampling period & Dates & Sites & Season & Reproduction \\
\hline 1 & Jul-Aug 2005 & F2, F3, C3 & Wet & Breeding \\
2 & Nov-Dec 2005 & F1, F2, F3 & Dry & Non-breeding \\
3 & Mar-Apr 2005 & F1, F2, F3, C2, C3, C4 & Dry & Breeding \\
4 & May-Jul 2006 & F1, F2, F3, C1, C2, C3, C4 & Wet & Breeding \\
5 & Feb-Mar 2007 & F1, F2, F3, C1, C2, C3 & Dry & Breeding \\
6 & Jun-Jul 2007 & F1, F2, F3, C1, C2, C3 & Breeding \\
7 & Sept-early Nov 2007 & F1, F2, F3, C1, C2, C3 & Wet & Dry \\
8 & mid Nov 2007-Jan 2008 & F1, F2, F3, C1, C2, C3 & Non-breeding \\
\hline
\end{tabular}

Sites with an $\mathrm{F}$ indicate a forest site and sites with a $\mathrm{C}$ indicate a coffee site.

study area from 2009 to 2010 (557 birds captured; Peters and Greenberg 2012) showed that banded birds were rarely captured in multiple sites (only the highly mobile species, clay-colored thrush Turdus grayi; $\mathrm{CCTH}$, was recaptured in multiple sites). The following morphometric measurements were obtained from each captured individual: body weight, culmen, tarsometatarsal length and width, and wing cord. If sexually dimorphic, gender was noted. If displaying juvenile characteristics, approximate age was determined. Other information noted and recorded included: molting pattern, any physical abnormality, and the presence of brood patch or egg in the abdomen. If a bird was recaptured within the same 2-3 month sampling period, no samples were collected again. All avian capture and handling techniques were reviewed and approved by the University of Georgia's Animal Care and Use Committee and a scientific permit granted by Costa Rica's Ministry of the Environment (MINAE).

\section{Target Species}

Although all birds (except hummingbirds) captured in mist nets were processed, due to cost and sample availability, six focal species were selected for specific analyses (e.g., paramyxovirus and Mycoplasma spp. testing). The following six species were selected as focal species: long-tailed manakin (Chiroxiphia linearis; LTMA), white-eared ground sparrow (Melozone leucotis; WEGS), rufous-capped warbler (Basileuterus rufifrons; RCWA), blue-crowned motmot (Momotus momota; BCMO), rufous-and-white wren (Thryothorus rufalbus; RWWR), and the orange-billed nightingale thrush (Catharus aurantiirostris; OBNT) (Table 2). Species were chosen based on the following criteria: (1) they were among the top ten most frequently captured species in both habitat types, (2) they represented a variety of foraging guilds (Stiles and Skutch 1989), (3) they were permanent residents (e.g., not Neotropical migrants), (4) they represented a variety of foraging height positions-from ground to middle canopy (which might be related to disease transmission, particularly from backyard chickens which are strict ground foragers), and (5) they were large enough for blood collection without harming the bird. In addition, we are fairly confident that individuals from these six species represented the habitat type in which they were captured, as no individuals of these species were ever captured in multiple sites, neither during our study nor during another 2-year mark-recapture study conducted in the region after our study (Peters and Greenberg 2012). Furthermore, although home range data are not available for the majority of neotropical resident bird species, the home range size of the OBNT as well as a different Chiroxiphia sp. from Brazil were studied, and found to be $<2$ ha (Sekercioglu et al. 2007; Hansbauer et al. 2008)—similar to the size of the coffee plantations used in our study (ranged from 1-2 ha).

\section{Avian Health Parameters}

One objective and two subjective health scores were obtained: (1) standardized body mass, (2) a body condition score based on palpable pectoral muscle density, and (3) an ectoparasite score. The standardized body mass was calculated as either body weight/tarsus length or body weight/ wing cord, which are acceptable methods for standardizing body mass (Gosler 2004). Body condition based on pectoral muscle density was scored from 1 to 5 such that $1=$ emaciated, $2=$ thin, $3=$ ideal, $4=$ overweight, and 5 = obese (Romagnano 1999). An ectoparasite score was generated by counting mites on one wing and ranged from 


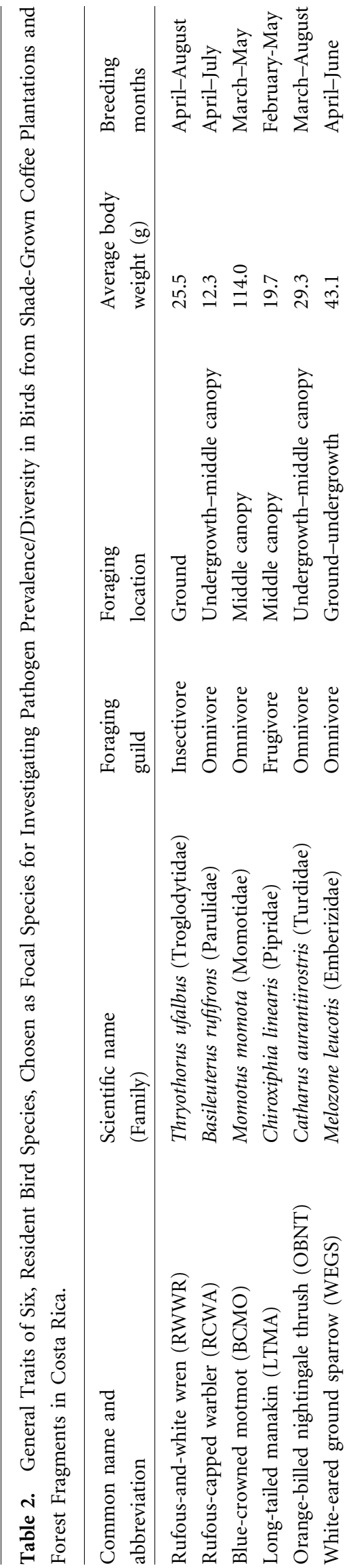

1 to $5 ; 1=$ no mites noted, $2=1-25$ mites, $3=25-50$ mites, $4=50-100$ mites, and $5=>100$ mites (Gosler 2004).

\section{Serology}

Blood collection was the last procedure performed before returning birds to individual paper bags for release. Venipuncture was achieved from the jugular vein in birds which weighed $>20 \mathrm{~g}$, whereas the superficial ulnar vein was utilized in birds $<20 \mathrm{~g}$. Ulnar vein puncture and blood collection with a heparin-lined capillary tube was achieved in birds that weighed $\leq 10-15 \mathrm{~g}$. Blood samples were not collected from birds weighing $<10 \mathrm{~g}$. No more than $1 \%$ of body weight of blood volume was collected from any individual. Blood tubes collected in the field were maintained in a cooler with ice and centrifuged no more than $8 \mathrm{~h}$ after collection. Following centrifugation, the plasma was transferred to cryovials, and frozen in a $-80^{\circ} \mathrm{C}$ freezer until processing. In order to determine pathogen seroprevalence, hemagglutination inhibition was performed to detect antibodies against paramyxovirus serotype 1 as previously described (Alexander and Senne 2008), and whenever plasma volume allowed, Mycoplasma gallisepticum and M. synoviae (Luttrell and Fischer 2007). Because of the difficulty of obtaining homologous red blood cells for testing a variety of wild species, chicken erythrocytes were used as agglutination indicators (Luttrell et al. 2001).

\section{Mycoplasma spp. Nucleic Acid Detection}

Choanal swabs were collected from the aforementioned target species to determine the presence of Mycoplasma gallisepticum and/or M. synoviae nucleic acid. The swabs were placed into $1.5 \mathrm{ml}$ microcentrifuge tubes containing $300 \mu \mathrm{l}$ of sterile phosphate buffered saline. On the day of collection, DNA was extracted utilizing a commercial available Qiamp Mini kit (Qiagen, Valencia, CA) following the manufacturer's recommendations. The resultant solution was frozen at $-70^{\circ} \mathrm{C}$ until processing. To determine the presence of Mycoplasma gallisepticum DNA, a Real-time Taqman $^{\circledR}$ polymerase chain reaction (RT-PCR) was utilized as previously described (Callison et al. 2006). A plasmid containing the amplification target sequence of the MGA0319 gene (lp gene; GenBank Accession \# NC_004829) previously described by Callison et al. (2006) was utilized as positive control. To determine the presence of Mycoplasma synoviae DNA in each sample, a PCR assay 
was utilized as previously described by Roy et al. (2003). Positive controls utilized were reference strains WVU1853 and F102AS.

\section{Paramyxovirus Amplification and Isolation}

Cloacal swabs were aseptically collected from target species. The swabs were immersed in sterile microcentrifuge tubes containing Dulbecco's Modification of Eagle's Medium (Mediatech, Manassas, VA) cell culture media with added antimicrobials (amphotercin B at $1 \%$, gentamicin at $0.1 \%$, and penicillin/streptinomycin at a concentration of $5,000 \mathrm{IUs} \mathrm{ml}^{-1}$ ) and frozen for later processing. To realize virus amplification and isolation, the tubes were vortexed, the swabs were discarded, and the tubes were centrifuged at 10,000 rpm for $5 \mathrm{~min}$. The supernatant was loaded onto a sterile syringe and injected into ten-day-old embryonated chicken eggs. After $72 \mathrm{~h}$, allantoic fluid was collected and utilized for a hemagglutination assay as previously described (Alexander and Senne 2008). One drop of fluid from each isolate was placed on cards designed to inactivate cells, yet capture and preserve nucleic acid (FTA@ classic cards, Whatman International Ltd, Springfield Mill, James Whatman Way, Maidstone, Kent, UK) for storage. Extraction of RNA from the FTA cards for the molecular detection of Newcastle disease virus was performed as previously described (Perozo et al. 2006).

\section{Enteric, Ecto, and Hemoparasites}

Fecal samples, when available, were collected from the paper bags used to hold the birds and preserved in a $2.5 \%$ potassium dichromate solution at room temperature until examined. Samples were examined directly, by fecal smear, and by standard flotation technique with Sheather's sugar solution microscopically (Taylor et al. 2007). Birds were examined for the presence of arthropods by systematically parting the feathers on the head, neck, and body to inspect for ectoparasites such as ticks and by extending one wing fully against a light source to inspect for feather mites. Feather mites were collected by sharply dissecting a small window of mite and mite eggs on the wing feathers. Body and feather lice, ticks, or parasitic flies were collected directly. All arthropods were stored in 70\% ethanol and identified by morphological characteristics. A thin blood smear was made immediately after blood collection. The blood smears were dried, stained with Wright's stain, and examined for the presence or absence of hemoparasites in the following manner. The entire slide was scanned at $100 \times$ for the presence of microfilaria or other large hemoparasites and to find the most appropriate area to examine at higher magnification. The slide was then scanned at 1,000 $\times$ under oil immersion for at least $10 \mathrm{~min}$ to examine for hemoparasites (Taylor et al. 2007). All suspect blood smears with hemoparasites were subsequently reviewed by a clinical pathologist at the University of Georgia's College of Veterinary Medicine who confirmed the identification.

\section{Statistical Analyses}

For avian health parameters, a repeated measures mixed model that recognized multiple observations as belonging to the same bird when repeated captures occurred was used to analyze health parameters for differences due to habitat type (coffee vs. forest), season (wet vs. dry), or reproductive season (breeding vs. non-breeding) for each of six target species separately. We defined the wet season as captures taking place between May and December and dry season as those from January to April. We defined reproductive season as that period of time in which birds are actively engaged in courtship, nest building, or caring for young, according to Stiles and Skutch (1989). Habitat type, season, reproductive season, and a habitat $\times$ season interaction term were included in the model as fixed variables while band ID and site were included as random factors. All models were fit using Restricted maximum likelihood because our design was unbalanced (Bolker et al. 2009). In addition, LTMA were tested for gender and age effects and WEGS were tested for age effects using a repeated measures model. Factors such as habitat type, age, or gender and a 2-way interaction effect were included in the model. If reproductive season was significant it was also included in the model. All hypothesis tests were 2-sided and the significance level was $\alpha=0.05$. The analysis was performed using PROC MIXED in SAS V 9.1 (Cary, NC).

For hemoparasites and endoparasites, $\chi^{2}$ tests were used to test for associations between the presence/no detection of Haemoproteus or microfiliaria, or, in the case of endoparasites, the presence/absence of five categories of endoparasites (coccidian, cestode, trematode, acanthocephalan, and nematode), and habitat type (coffee and forest). If there were $<24$ birds captured in a species, then Fisher's exact test was used instead, as birds were needed in each of the four boxes of the $2 \times 2$ contingency table for tests of association to be performed. When a significant difference between coffee and forest was found for a specific 
species, $\chi^{2}$ analysis was used to determine if there was a difference by specific sampling site. A score (0-5) reflecting the different categories of parasites infecting an individual bird was created to illustrate the "richness" of parasite fauna. A repeated measures mixed model was used to test the total number of endoparasite infections for differences due to habitat type (forest vs. coffee), season (wet vs. dry), or reproductive season (breeding vs. non-breeding) for all species pooled. Habitat type, season, reproductive season, and a habitat $\times$ season interaction term were included in the model as fixed variables while band identification and site were included as random factors. An unstructured covariance structure was used.

\section{Results}

A total of 1,561 birds representing 75 species were captured across all coffee and forest sites from July 2005 to January 2008 (Table 4). Of those birds captured, 773 birds representing 62 species were captured in coffee sites and 788 birds of 47 species were captured in forest sites. The total number of birds that were re-captured at least once was 157 individuals, and of those, $73 \%$ (115 individuals) were re-captured only once, $20 \%$ (31 individuals) were re-captured twice, $4 \%$ (6 individuals) were re-captured three times, and 3\% (5 individuals) were re-captured four times or more. Of the birds that were re-captured only once, the majority, 70\% (80 individuals), were re-captured in a different sampling period from the sampling period of original capture.

\section{Avian Health Parameters}

Measures of body condition were affected by a variety of factors, depending on the species (Table 3). Of importance, ectoparasite scores were significantly higher in juvenile compared to adult LTMA, during wet compared to dry seasons for RWWR, and in forested compared to shade coffee habitats for both WEGS and OBNT. The body condition scores of RWWR, WEGS, and LTMA were significantly higher during the dry season, compared to the wet season, and additionally during the non-reproductive period for LTMA.

\section{Serology}

We tested 556 birds of 31 species (coffee $=300$; forest $=256$; Table 4) for paramyxovirus- 1 . We detected antibodies in five birds [ $<1 \%$; two BCMO, one RWWR, one WEGS, and one buff-throated saltator (Saltator maximus; BTSA)]. Four of those birds were captured on coffee plantations and one (WEGS) was captured in forest. We tested 241 individual birds $(24$ species; coffee $=101$; forest $=140$; Table 4 ) for antibodies against Mycoplasma gallisepticum and M. synoviae, of which no bird was positive.

\section{Mycoplasma spp. Nucleic Acid Detection and Paramyxovirus Amplification and Isolation}

Two hundred and twenty choanal and cloacal swabs were collected during three sampling bouts from the target species and processed for DNA detection of M. gallisepticum and M. synoviae and virus isolation for paramyxovirus. All samples were negative. Since all results were negative for Mycoplasma spp. and paramyxovirus, they are excluded from further discussion. Table 5 displays the distribution of samples obtained.

\section{Enteric, Ecto, and Hemoparasites}

We examined 243 fecal samples (coffee $=130$; forest $=113)$ from 39 species $($ coffee $=27$; forest $=27)$ of birds. The parasites examined were divided into 5 taxonomic categories: coccidia, cestode, trematode, acanthocephalan, and nematode. Prevalence of infection (samples positive for any category of parasite/all samples examined) was 51 and $46 \%$ for coffee and forest, respectively (Table 6). Only one statistically significant result was found by habitat type. Clay-colored thrushes had a higher prevalence of infection with coccidian parasites in forest $(67 \%)$ than coffee $(21 \%)(p=0.0368)$. For all other species there was not enough data or the associations were not significant. Larvated eggs of Syngamus trachea, a nematode typically associated with chickens, were found in three CCTH and one OBNT captured in shade-coffee plantations and a white-throated thrush (Turdus assimilis; WTTH) captured in forest.

The mites collected from the wing feathers (and utilized for the ectoparasites score) were identified as Pterolichus obtusus (Pterolichidae), Trouessartia sp. (Trouessartiidae), Amerodectes $n$. sp. (Proctophyllodidae), or Falculifer sp. $n r$. dinoceras (Falculiferidae). Lice collected were identified as Sturnidoecus caligineus (Philopteridae; Carriker, 1903), Brueelia sp. (Philopteridae), or Myrsidea sp. (Philopteridae). Two burrowing mites were identified as Eutrombicula batatas and Blankaartia sinnamaryi 


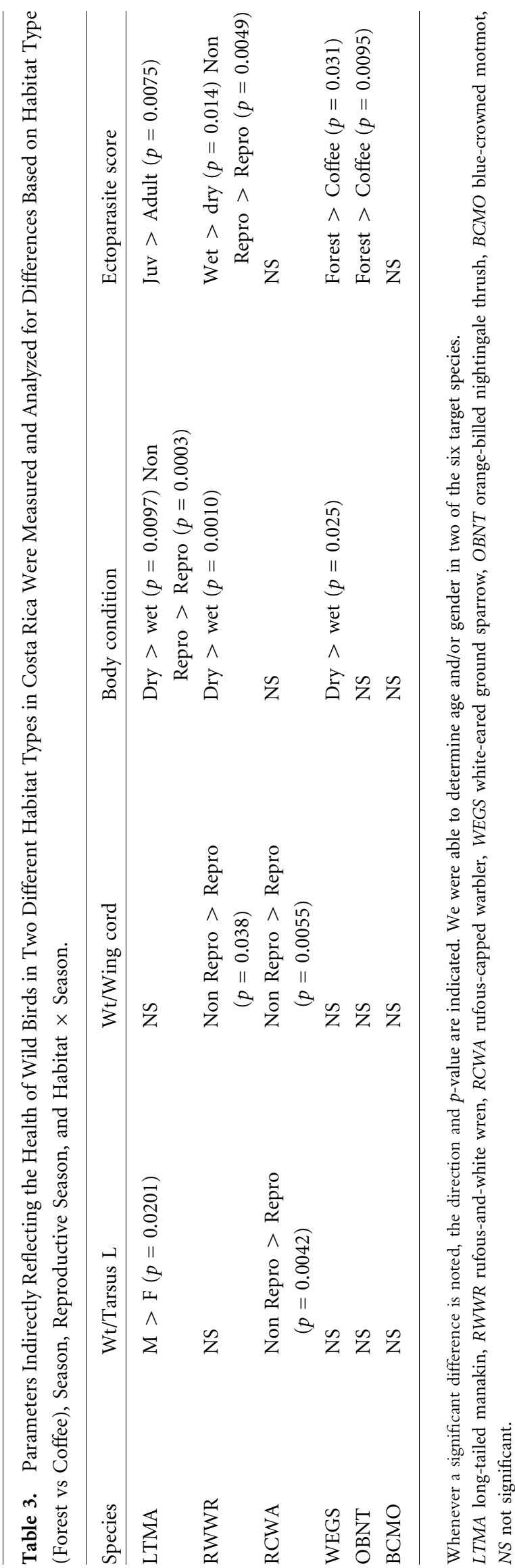

(Trombiculidae; Floch and Fauran 1956), the latter of which was always associated with raised, firm, round, fibrotic inflammatory skin lesions. Ticks were identified as Ixodes spinipalpis or Amblyomma sp. (Ixodidae) larvae, which could not be identified to species (Nuttall 1916). Interestingly, Pterolichus obtusus (Pterolichidae), a common mite of chickens, were collected from 5 RCWA and 10 house wrens (Troglodytes aedon), all from shade-coffee plantations. Parasitic flies (Hippoboscidae) were found infrequently on BCMO, СCTH, and other larger birds ( $>40 \mathrm{~g}$ ). Significant differences in the mean ectoparasites scores were found for OBNT (forest $>$ coffee, $p=0.0095$ ), RWWR (wet $>$ dry, $p=0.0140$; non-breeding $>$ breeding, $p=0.0049$ ), LTMA (juvenile $>$ adult; $p=0.0075$ ), and WEGS (forest $>$ coffee; $p=0.0316$ ) (Table 3 ).

We examined 1,121 blood smears from 68 species of birds. Only two hemoparasites were detected, Haemoproteus sp. and microfilaria. Of all the birds examined, $16 \%$ ( $n=178)$ of 23 species were infected with one of the two parasites (Table 4). There were no significant associations between the various factors tested and the presence of microfilaria. A difference by habitat type was found for WEGS such that prevalence of infection was higher in birds captured in shade-coffee plantations $(p=0.0494)$.

\section{Discussion}

Based on our results, shade-coffee plantations do not appear to be habitats that facilitate disease transmission, or affect individual bird health; however, when compared with forest fragments, some differences in pathogen prevalence and diversity emerged.

\section{Avian Health Parameters}

Not surprisingly, standardized body mass measurements did not differ by habitat type. It is important to consider, however, that our capture methodology (mist-net captures) may be responsible for selecting individuals that are at least able to fly and may obscure true differences.

The feather mites identified in this study are not thought to be pathogenic, although some controversy exists regarding the damage that feather mites can cause to the feather pith or while gnawing through the feather shaft, weakening the feather prematurely (Proctor 2003). Birds of at least two species (CCTH and WEGS) captured in our study with high feather mite loads showed poor feather 
Table 4. Common Name, Bird Code, and Scientific Name of all Bird Species Captured.

\begin{tabular}{|c|c|c|c|c|c|c|c|c|}
\hline \multirow[t]{2}{*}{ Common name } & \multirow[t]{2}{*}{ Code } & \multirow[t]{2}{*}{ Scientific name } & \multicolumn{2}{|c|}{ Paramyxovirus-1 } & \multicolumn{2}{|c|}{$\begin{array}{l}\text { Mycoplasma } \\
\text { gallisepticum } \\
\text { and M. synoviae }\end{array}$} & \multicolumn{2}{|c|}{$\begin{array}{l}\text { Haemoproteus } \\
\text { spp. }\end{array}$} \\
\hline & & & Coffee & Forest & Coffee & Forest & Coffee & Forest \\
\hline Alder flycatcher & ALFL & Empidonax alnorum & & & & & $0(1)$ & $0(0)$ \\
\hline Baltimore oriole & BAOR & Icterus galbula & $0(4)$ & $0(0)$ & $0(1)$ & $0(0)$ & $3(4)$ & $0(0)$ \\
\hline Barred antshrike & BAAN & Thamnophilus doliatus & & & & & $0(1)$ & $0(0)$ \\
\hline Northern barred-woodcreeper & BAWO & Dendrocolaptes sanctithomae & $0(0)$ & $0(6)$ & $0(0)$ & $0(2)$ & $0(0)$ & $0(5)$ \\
\hline Black-and-white warbler & BWWA & Mniotilta varia & & & & & $0(1)$ & $0(1)$ \\
\hline Black-headed nightingale thrush & BHNT & Catharus mexicanus & & & & & $0(0)$ & $0(1)$ \\
\hline Blue-crowned motmot & $\mathrm{BCMO}$ & Momotus momota & $2(17)$ & $0(10)$ & $0(11)$ & $0(4)$ & $0(24)$ & $0(10)$ \\
\hline Blue-gray tanager & BGTA & Thraupis episcopus & $0(3)$ & $0(0)$ & $0(2)$ & $0(0)$ & $1(6)$ & $0(0)$ \\
\hline Boat-billed flycatcher & BBFL & Megarhyncus pitangua & $0(1)$ & $0(0)$ & $0(1)$ & $0(0)$ & $0(1)$ & $0(0)$ \\
\hline Brown jay & BRJA & Psilorhinus morio & $0(1)$ & $0(0)$ & $0(1)$ & $0(0)$ & $0(1)$ & $0(0)$ \\
\hline Buff-throated saltator & BTSA & Saltator maximus & $1(7)$ & $0(1)$ & $0(2)$ & $0(1)$ & $2(12)$ & $0(0)$ \\
\hline Canada warbler & CAWA & Cardellina canadensis & & & & & $0(2)$ & $0(1)$ \\
\hline Chiriqui quail-dove & CQDO & Geotrygon chiriquensis & & & & & $1(1)$ & $0(0)$ \\
\hline Clay-colored thrush & ССТH & Turdus grayi & $0(74)$ & $0(20)$ & $0(23)$ & $0(10)$ & $16(84)$ & $2(18)$ \\
\hline Common bush-tanager & CBTA & Chlorospingus ophthalmicus & & & & & $0(0)$ & $2(3)$ \\
\hline Dusky-capped flycatcher & DCFL & Myiarchus tuberculifer & $0(0)$ & $0(3)$ & & & $0(16)$ & $0(4)$ \\
\hline Blue-throated toucanet & EMTO & Aulacorhynchus caeruleogularis & $0(5)$ & $0(4)$ & $0(2)$ & $0(2)$ & $0(6)$ & $0(5)$ \\
\hline Eye-ringed flatbill & ERFL & Rhynchocyclus brevirostris & $0(0)$ & $0(1)$ & & & $0(0)$ & $0(1)$ \\
\hline Golden-crowned warbler & GCWA & Basileuterus culicivorus & & & & & $0(1)$ & $4(10)$ \\
\hline Grayish saltator & GRSA & Saltator coerulescens & $0(2)$ & $0(0)$ & $0(1)$ & $0(0)$ & $0(2)$ & $0(0)$ \\
\hline Great kiskadee & GRKI & Pitangus sulphuratus & $0(1)$ & $0(0)$ & $0(1)$ & $0(0)$ & $0(2)$ & $0(0)$ \\
\hline House wren & HOWR & Troglodytes aedon & & & & & $1(13)$ & $0(2)$ \\
\hline Keel-billed toucan & KBTO & Ramphastos sulfuratus & & & & & $0(0)$ & $0(1)$ \\
\hline Kentucky warbler & KEWA & Geothlypis formosa & & & & & $0(0)$ & $0(4)$ \\
\hline Least flycatcher & LEFL & Empidonax minimus & & & & & & \\
\hline Lesser elaenia & LEEL & Elaenia chiriquensis & & & & & & \\
\hline Lesser greenlet & LEGR & Hylophilus decurtatus & & & & & $0(0)$ & $3(4)$ \\
\hline Long-tailed manakin & LTMA & Chiroxiphia linearis & $0(4)$ & $0(3)$ & $0(2)$ & $0(0)$ & $0(45)$ & $0(116)$ \\
\hline Louisiana waterthrush & LAWA & Parkesia motacilla & & & & & & \\
\hline Paltry tyrannulet & MITY & Zimmerius vilissimus & & & & & $0(1)$ & $0(0)$ \\
\hline Mountain elaenia & MOEL & Elaenia frantzii & & & & & $0(0)$ & $0(1)$ \\
\hline Mountain thrush & MORO & Turdus plebejus & $0(3)$ & $0(0)$ & & & $0(2)$ & $0(0)$ \\
\hline Ocher-bellied flycatcher & OBFL & Mionectes oleagineus & & & & & $0(4)$ & $0(19)$ \\
\hline Olivaceous woodcreeper & OLWO & Sittasomus griseicapillus & & & & & $0(0)$ & $0(7)$ \\
\hline Olive-striped flycatcher & OSFL & Mionectes olivaceus & & & & & $0(2)$ & $0(2)$ \\
\hline Orange-bellied trogon & OBTR & Trogon aurantiiventris & & & & & & \\
\hline Orange-billed nightingale thrush & OBNT & Catharus aurantiirostris & $0(47)$ & $0(51)$ & $0(6)$ & $0(23)$ & $3(50)$ & $8(64)$ \\
\hline Ovenbird & OVN & Seiurus aurocapilla & & & & & $0(1)$ & $0(7)$ \\
\hline Philadelphia vireo & PHVI & Vireo philadelphicus & & & & & $0(1)$ & $0(0)$ \\
\hline Plain wren & PLWR & Thryothorus modestus & $0(2)$ & $0(1)$ & & & $2(20)$ & $0(3)$ \\
\hline Plain xenops & PLXE & Xenops minutus & & & & & & \\
\hline Red-crowned ant-tanager & RCAT & Habia rubica & $0(0)$ & $0(11)$ & $0(0)$ & $0(4)$ & $0(0)$ & $0(12)$ \\
\hline Red-eyed vireo & REVI & Vireo olivaceus & & & & & $2(2)$ & $0(0)$ \\
\hline
\end{tabular}


Table 4. continued

\begin{tabular}{|c|c|c|c|c|c|c|c|c|}
\hline \multirow[t]{2}{*}{ Common name } & \multirow[t]{2}{*}{ Code } & \multirow[t]{2}{*}{ Scientific name } & \multicolumn{2}{|c|}{ Paramyxovirus-1 } & \multicolumn{2}{|c|}{$\begin{array}{l}\text { Mycoplasma } \\
\text { gallisepticum } \\
\text { and M. synoviae }\end{array}$} & \multicolumn{2}{|c|}{ Haemoproteus spp. } \\
\hline & & & Coffee & Forest & Coffee & Forest & Coffee & Forest \\
\hline Rufous-breasted wren & RBWR & Thryothorus rutilus & & & & & $0(0)$ & $0(1)$ \\
\hline Ruddy woodcreeper & RUWO & Dendrocincla homochroa & $0(4)$ & $0(27)$ & $0(3)$ & $0(17)$ & $0(7)$ & $0(33)$ \\
\hline Rufous-browed peppershrike & $\mathrm{RBPE}$ & Cyclarhis gujanensis & $0(2)$ & $0(0)$ & & & $1(2)$ & $0(0)$ \\
\hline Rufous-capped warbler & RCWA & Basileuterus rufifrons & $0(1)$ & $0(0)$ & & & $1(33)$ & $3(36)$ \\
\hline Rufus-and-white wren & RWWR & Thryothorus rufalbus & $1(24)$ & $0(25)$ & $0(9)$ & $0(15)$ & $0(32)$ & $0(27)$ \\
\hline Passerini's tanager & SRTA & Ramphocelus passerinii & & & & & $0(0)$ & $0(1)$ \\
\hline Silver-throated tanager & STTA & Tangara icterocephala & $0(1)$ & $0(0)$ & & & $0(1)$ & $0(0)$ \\
\hline Streak-headed woodcreeper & SHWO & Lepidocolaptes souleyetii & $0(3)$ & $0(2)$ & $0(0)$ & $0(2)$ & $0(5)$ & $0(1)$ \\
\hline Swainson's thrush & SWTH & Catharus ustulatus & $0(11)$ & $0(6)$ & $0(6)$ & $0(4)$ & $2(14)$ & $0(8)$ \\
\hline Tennessee warbler & TEWA & Oreothlypis peregrina & & & & & $0(1)$ & $0(0)$ \\
\hline Wedge-billed woodcreeper & WWOC & Glyphorhynchus spirurus & & & & & $1(1)$ & $0(0)$ \\
\hline Western wood-pewee & WWPE & Contopus virens & & & & & $0(2)$ & $0(0)$ \\
\hline White-eared ground sparrow & WEGS & Melozone leucotis & $0(56)$ & $1(45)$ & $0(20)$ & $0(38)$ & $52(62)$ & $41(60)$ \\
\hline White-throated thrush & WTTH & Turdus assimilis & $0(7)$ & $0(24)$ & $0(2)$ & $0(12)$ & $1(6)$ & $0(7)$ \\
\hline White-tipped dove & WTDO & Leptotila verreauxi & $0(7)$ & $0(5)$ & $0(4)$ & $0(3)$ & $0(7)$ & $0(5)$ \\
\hline Wilson's warbler & WIWA & Cardellina pusilla & & & & & $0(5)$ & $0(2)$ \\
\hline Wood thrush & WOTH & Hylocichla mustelina & $0(4)$ & $0(6)$ & $0(3)$ & $0(2)$ & $0(9)$ & $5(23)$ \\
\hline Worm-eating warbler & WEWA & Helmitheros vermivorum & & & & & $0(0)$ & $0(1)$ \\
\hline Yellow-bellied flycatcher & YBFL & Empidonax flaviventris & & & & & $0(3)$ & $0(0)$ \\
\hline Yellow tyrannulet & YETY & Capsiempis flaveola & & & & & $0(1)$ & $0(2)$ \\
\hline Yellow-bellied elaenia & YBEL & Elaenia flavogaster & & & & & $0(3)$ & $0(0)$ \\
\hline Yellow-billed cacique & YBCA & Amblycercus holosericeus & & & & & $1(2)$ & $0(1)$ \\
\hline Yellow-crowned euphonia & YCEU & Euphonia luteicapilla & & & & & $0(3)$ & $0(0)$ \\
\hline Yellow-faced grassquit & YFGR & Tiaris olivacea & & & & & $0(10)$ & $0(0)$ \\
\hline Yellow-green vireo & YGVI & Vireo flavoviridis & & & & & $11(13)$ & $0(0)$ \\
\hline Yellowish flycatcher & YEFL & Empidonax flavescens & & & & & $0(0)$ & $0(1)$ \\
\hline Yellow-margined flycatcher & YMFL & Tolmomyias assimilis & & & & & $0(1)$ & $0(0)$ \\
\hline White-naped brush finch & YTBF & Atlapetes albinucha & $0(9)$ & $0(3)$ & $0(0)$ & $0(1)$ & $6(12)$ & $3(4)$ \\
\hline Yellow-throated euphonia & YTEU & Euphonia hirundinacea & $0(0)$ & $0(2)$ & $0(1)$ & $0(0)$ & $0(53)$ & $0(11)$ \\
\hline Yellow-throated vireo & YTVI & Vireo flavifrons & & & & & $0(2)$ & $0(0)$ \\
\hline Total birds & & & $4(300)$ & $1(256)$ & $0(101)$ & $0(140)$ & 107(596) & $71(525)$ \\
\hline
\end{tabular}

Numbers in columns show the number of birds tested in each habitat type for focal pathogens. All individuals were tested via hemagglutination inhibition to detect for antibodies against avian paramyxovirus-1, avian Mycoplasma gallisepticum and M. synoviae. The first number in each column denotes the number of individuals seropositive and the number in parenthesis is the number of birds sampled.

condition, much like chickens maintained in high-density corrals. Significant factors that affect arthropod loads in hosts include species susceptibility, age, gender, and immune system status, or extrinsic factors, such as salt spray (Dowling et al. 2001) but the literature agrees that molting stage is the single most important factor influencing ectoparasite loads, such that birds have the lowest ectoparasite load immediately after the molting period
(Young and McDonald 2000). The chewing lice recovered from wild birds were consistent with previous records of chewing lice on neotropical birds (Lindell et al. 2002) and these ectoparasites can cause significant irritation in high numbers (Lindell et al. 2002). Specifically, Pterolichus obtusus, the feather mite of chickens, can cause irritation and foraging disruption (D'Souza et al. 2001). These mites have been found in high numbers on chickens in the region 
Table 5. Distribution of Choanal and Cloacal Samples Obtained From Birds in Costa Rica for M. gallisepticum and M. synoviae DNA Extraction and Paramyxovirus Isolation.

\begin{tabular}{lccc}
\hline \multirow{2}{*}{ Species } & Total sampled & \multicolumn{2}{c}{ Habitat type } \\
\cline { 3 - 4 } & & Coffee & Forest \\
\hline BCMO & 17 & 13 & 4 \\
LTMA & 59 & 14 & 45 \\
OBNT & 40 & 21 & 19 \\
RWWR & 21 & 8 & 13 \\
WEGS & 43 & 30 & 13 \\
RCWA & 27 & 8 & 22 \\
Total & 220 & 94 & 116 \\
\hline
\end{tabular}

All samples were negative.

Table 6. Percent of Endoparasite Infection, as Determined From Examining 243 Fecal Samples From 39 Avian Species, by Parasite Category in Coffee and Forest Habitats.

\begin{tabular}{lll}
\hline Parasite & \multicolumn{2}{l}{ Percent of infection } \\
\cline { 2 - 3 } & $\begin{array}{ll}\text { Coffee } \\
(n=130)(\%)\end{array}$ & $\begin{array}{l}\text { Forest } \\
(n=113)(\%)\end{array}$ \\
\hline Coccidia & 31 & 39 \\
Cestode & 12 & 3 \\
Acanthocephalan & 4 & 2 \\
Trematode & 4 & 2 \\
Nematode & 18 & 9 \\
\hline
\end{tabular}

(Hernandez-Divers et al. 2008). We only found these mites in birds captured from coffee plantations, where we have observed wild birds feeding, roosting, and dust bathing in areas that chickens frequent. This mite can live off its primary host for several days; thus, it is possible that sharing of dust baths, or other areas of high-density by wild birds and chickens could lead to temporary infestation of wild birds with chicken-associated mites (Proctor 2003). Ectoparasite scores varied significantly by habitat for WEGS and OBNT (forest $>$ coffee). This could be explained by microclimatic preferences of the mites themselves as they prefer cooler, more humid environments (Dubinin 1951).

\section{Serology, Virus Isolation, and Nucleotide Detection}

We detected antibodies against paramyxovirus-1 in five birds but were unable to isolate virus from any of the cloacal swabs we collected. Thus, we are unable to make any inference about the differences in paramyxovirus exposure and habitat type. Similarly, we did not detect antibodies against Mycoplasma spp. or Mycoplasma DNA. We can rule out sample handling and laboratory methodology because we always utilized chickens from the region as "controls," for which we both detected antibodies and viral/bacterial nucleotides. The test utilized in this study, hemagglutination inhibition, has not been validated for every species tested in this study; however, it has been used extensively to detect both natural and experimental infections of AMPV-1 and Mycoplasma spp. of non-domestic birds (e.g., Barton et al. 1992; Hofle et al. 2002; Luttrell et al. 1996; Luttrell and Fischer 2007).

The prevalence of paramyxovirus in wild passerines is generally considered to be very low (Morishita et al. 1999; Schnebel et al. 2005; Stanislawek et al. 2001) and indeed our study indicates that this population of wild birds has a very low exposure to avian paramyxovirus. As part of an investigation following an Newcastle disease virus outbreak in commercial chickens, Goodman and Hanson (1988) sampled $>800$ birds from various regions in Costa Rica and isolated parmyxovirus-2 from a single finch, a wren, and a chicken from three different localities. Although the data are scarce, it appears that avian paramyxovirus-2 (APMV-2) might be the type most prevalent in Passeriformes. Since cross-reactivity when testing for AMPV-1 and -2 is currently unknown for this variety of avian species, and to account for the low prevalence of this pathogen, further studies should consider larger sample sizes and testing for both types of AMPV (Leighton and Heckert 2007). Similarly, we failed to detect birds that had antibodies to either Mycoplasma gallisepticum or M. synoviae. We did address the limitations of testing for antibodies by surveying our target species for antigen (either paramyxovirus through virus isolation or Mycoplasma through PCR). Other than the recent emergence of M. gallisepticum, and M. sturni in house finches Carpodacus mexicanus, and European starlings Sturnus vulgaris, respectively, the prevalence of Mycoplasma infections, particularly those that might cause disease in passerines is relatively unknown (Friend and Franson 1999-2001; Luttrell and Fischer 2007). These pathogens require direct contact for transmission. Given the relatively high prevalence of paramyxovirus and Mycoplasma spp. in the chickens we surveyed in the same shade-grown coffee plantations where we were capturing wild birds (Hernandez-Divers et al. 2008), if direct contact between chickens and wild birds was common, we would expect to see some evidence in susceptible wild birds. 


\section{Parasites}

Patterns of parasitism in bird populations are influenced by host density, behavior, intraspecific and interspecific contact rates, diet, and home ranges, all of which can be affected by human-associated changes to the landscape (Gillespie et al. 2005). Since assessing severity of infection from fecal egg and larvae counts is inappropriate, we are not making any inferences about the effects of parasites on the health of individual birds (Yabsley 2008). Whereas we did note a trend for higher species richness of parasites in birds inhabiting shade-coffee plantations, our results were not statistically significant. The only bird species that harbored more coccidian parasites in one habitat type (CCTH; forest $>$ coffee) is a highly mobile species, often foraging in open areas and breeding in forest fragments, and thus captured individuals could not be considered representative of any one habitat type (Stiles and Skutch 1989).

Avian hemoparasites have long been a focus of disease ecology, as some have hypothesized that they play a role in sexual selection (Loye and Zuck 1991). However, information regarding the distribution and prevalence of these parasites as well as their effect on individuals and populations is still patchy (Hartup et al. 2008). Our results were consistent with previous reports of the presence and prevalence of Haemoproteus spp. in Passeriformes, although to the best of our knowledge, this study represents a new host record for BTSA, OBNT, Chiriquí quail-dove (Geotrygon chiriquensis; CQDO), golden-crowned warbler (Basileuterus culicivorus; GCWA), rufous-browed peppershrike (Cyclarhis gujanensis; RBPE), and the yellow-billed cacique (Amblycercus holosericeus; YBCA). The higher prevalence of infection with Haemoproteus spp. during the non-breeding season for OBNT might be related to seasonal differences in foraging behavior and vector abundance, given that OBNT spends most of its time foraging on the ground outside the reproductive period, but shifts to midstory foraging while tending the nest. Our results should be interpreted in light of the limitations of our sampling method. Specifically, calculating the prevalence of microfilariae from blood smears from peripheral blood can underestimate infection, because these large parasites tend to concentrate in deep circulation (Holmstad et al. 2003).

White-eared ground sparrows from shade coffee had a significantly higher prevalence of infection with Haemoproteus spp. This could be explained by vector differences or differences in vector abundance between the two habitats in question. Anecdotally the authors encountered Culicoides spp. with more frequency, as evidenced by their bites, in coffee plantations than in forest. However, habitat differences in Haemoproteus prevalence were not found in any other bird species sampled in this study. Birds are infected with a wide variety of Haemoproteus species and the details of vector-parasite relationships in Costa Rica are currently unknown but could be elucidated with both molecular analyses of the parasite and simultaneous vector trapping (Dimitrov and Zehtindjie 2010).

Although, like us, Bennett et al. (1988) found no association between standardized body mass and prevalence of infection with hemosporidian parasites of passerines, it is likely that Haemoproteus has a significant effect on the fitness of an individual. Recent work has suggested that hemoparasites could cause adverse effects to the survival, physiology, and breeding performance of birds (DeGroote and Rodewald 2010; Martinez-de la Puente et al. 2010; Norte et al. 2009). Infections with Haemoproteus tend to be chronic, with relapses of parasitemia associated with periods of stress or food shortage (Atkinson 1991). Anecdotally, it is interesting to note that of the birds in our study that died as a result of excessive blood loss during blood collection $(n=4)$, three were WEGS (the species with the highest Haemoproteus prevalence, 76\%), and all three were infected with Haemoproteus, leading one to reasonably speculate that the stressors of handling and blood collection on an already-anemic and compromised bird would predispose it for mortality.

\section{Conclusions and Future Directions}

Our hypothesis- that birds inhabiting shade-grown coffee plantations would have lower health indicators and higher prevalence and diversity of pathogens when compared to those inhabiting forest fragments-was not supported by our data. However, in the case of pathogens present at low prevalence (e.g., paramyxovirus), and those that display temporal differences (e.g., vector-borne), sample size, or testing logistics may have likely limited our ability to test our hypothesis. Regardless, it appears that our suggested mechanisms-the introduction of chickens, the artificial concentration of wild birds, mixing various species that typically do not come together-have not played a role in changing the disease dynamics sufficiently to increase the prevalence and diversity of pathogens in avian communities living in shade-grown coffee.

Finally, we believe that our understanding of how human-related changes to the landscape affect wildlife 
disease dynamics is just beginning. Traditional wildlife disease investigation has focused on mortality and visible effects, while sublethal, yet significant effects on populations, particularly those of conservation concern, should be the focus of future studies, particularly in areas where sustainable agriculture is heavily promoted (Gillespie et al. 2005; Wobeser 2007). Even when taking into account the limitations of this study, we conclude that shade-coffee plantations do not pose a significant health risk to forest birds, but at least two groups of pathogens in this ecosystem would benefit from further attention: Haemoproteus and the diversity and identity of endoparasites.

\section{REFERENCES}

Alexander DJ, Senne DA) Newcastle disease virus and other avian paramyxoviruses. In: A Laboratory Manual for the Isolation, Identification, and Characterization of Avian Pathogens, DufourZavala DESL, Glisson JR, Pearson JE, Reed WM, Jackwood MW, Woolcock PR (editors), Athens: American Association of Avian Pathologists, pp 135-141

Atkinson CT) Pathogenicity and epizootiology of avian haematozoa: Plasmodium, Leucocytozoon and Haemproteus. In: BirdParasite Interactions: Ecology, Evolution and Behaviour, Loye MZ (editor), New York: Oxford University Press, pp 19-43

Barton JT, Bickford AA, Cooper GL, Charlton BR, Cardona CJ) Avian Paramyxovirus type 1 infections in racing pigeons in California I: clinical signs, pathology, and serology. Avian Diseases 36:463-468

Bennett GF, Caines JR, Bishop MA) Influence of blood parasites on the body mass of passeriform birds. Journal of Wildlife Diseases 24:339-343

Bibby CJ, Burgess ND, Hill DA, Mustoe SH) Birds Census Techniques, 2nd ed., London: Academic Press

Bolker BM, Brooks ME, Clark CJ, Geange SW, Poulson JR, Stevens $\mathrm{MHH}$, White JSS) Generalized linear mixed models: a practical guide for ecology and evolution. Trends in Ecology and Evolution 24:127-135

Callison SA, Riblet SM, Sun S, Ikuta N, Hilt D, Leiting V, Kleven SH, Suarez DL, Garcia M) Development and validation of a real-time Taqman $(\mathrm{R})$ polymerase chain reaction assay for the detection of Mycoplasma gallisepticum in naturally infected birds. Avian Diseases 50:537-544

Cohen EB, Lindell CA) Survival, habitat use, and movements of fledgling white-throated Robins (Turdus assimilis) in a Costa Rican agricultural landscape. Auk 121:404-414

D'Souza PE, Jagannath MS, Murthy KMS) Feather mite infestation in a broiler breeder farm. Veterinary Record 149:777a

DeGroote LW, Rodewald PG) Blood parasites in migrating woodwarblers (Parulidae): effects on refueling, energetic condition, and migration timing. Journal of Avian Biology 41:147-153

Dimitrov DP, Zehtindjie Bensch S) Genetic diversity of avian blood parasites in SE Europe: Cytochrome b lineages of the genera Plasmodium and Haemoproteus (Haemosporida) from Bulgaria. Acta Parasitologica 55:201-209

Dowling DK, Richardson DS, Blaakmeer K) Feather mite loads influenced by salt exposure, age and reproductive stage in the
Seychelles Warbler Acrocephalus sechellensis. Journal of Avian Biology 32:364-369

Dubinin VB) Feather mites (Analgesoidea). Part 1. Introduction to their study. Fauna USSR 6:1-363

Floch H, Fauran P) Two species of the genus Trombicula (Acariens, Trombiculidae) new for the fauna of French Guiana: Trombicula alfreddugesi (Oudemans, 1910) and Trombicula sinnamaryi n. sp.. Institut Pasteur de la Guyane française et de l'Inini 17:1-7

Friend M, Franson JC (1999-2001) Field manual of wildlife diseases: general field procedures and diseases of birds. Biological Resources Division, Information and Technology Report.

Gillespie TR, Chapman CA, Greiner EC) Effects of logging on gastrointestinal parasite infections and infection risk in African primates. Journal of Applied Ecology 42:699-707

Goodman BB, Hanson RP) Isolation of avian paramyxovirus-2 from domestic and wild birds in Costa Rica. Avian Diseases 32:713-717

Gosler A) Birds in the hand. In: Bird Ecology and Conservation, Sutherland WJ, Newton I, Green RE (editors), New York: Oxford University Press, pp 85-119

Groom MJ) Threats to biodiversity. In: Principles of Conservation Biology, Groom MJ, Meffe GK, Carroll CR (editors), Sunderland: Sinauer Associates Inc., pp 63-111

Hartup BK, Oberc A, Stott-Messick B, Davis AK, Swarthout ECH) Blood parasites of House Finches (Carpodacus mexicanus) from Georgia and New York. Journal of Wildlife Diseases 44:469-474

Hansbauer MM, Storch I, Pimentel RG, Metzger JP) Comparative range use by three Atlantic forest understorey bird species in relation to forest fragmentation. Journal of Tropical Ecology 24:291-299

Hernandez-Divers SM, Villegas P, Jimenez C, Hernandez-Divers SJ, Garcia MC, Riblet SM, Carroll CR, O’Connor BM, Webb JL, Yabsley MJ, Williams SM, Sanchez S) Backyard chicken flocks pose a disease risk for neotropical birds in Costa Rica. Avian Diseases 52:558-566

Hilton-Taylor, C (2000) 2000 IUCN red list of threatened species. International Union for the Conservation of Nature.

Hofle U, Blanco JM, Kaleta EF) Seroprevalence of avian paramyxovirus 1, 2, and 3 in captive and free-living birds of prey in Spain. Annals of the New York Academy of Sciences 969:213-216

Jha S, Bacon CM, Philpott SM, Rice RA, Ernesto Mendez V, Laderach P (2011) A review of ecosystem services, farmer livelihoods, and value chains in shade coffee agroecosystems. In: Integrating Agriculture, Conservation and Ecotourism: Examples From the Field, Campbell WB, Lopez Ortiz S (editors), Dordrecht: Springer, pp 141-208

Komar O) Ecology and conservation of birds in coffee plantations: a critical review. Bird Conservation International 16:1-23

Leighton FA, Heckert RA (2007) Viral Diseases. In: Infectious Diseases of Wild Birds, Thomas J, Hunter DB, Atkinson CT (editors), Ames: Blackwell Publishing Professional, pp 1-16

Lindell CT, Gavin TA, Price RD, Sanders AL) Chewing louse distributions on two Neotropical thrush species. Comparative Parasitology 69:212-217

Loye JE, Zuck M) Bird-Parasite Interactions: Ecology, Evolution, and Behavior, New York: Oxford University Press

Luttrell MP, Fischer JR, Stallknecht DE, Kleven SH) Field investigation of Mycoplasma gallisepticum infections in house finches (Carpodacus mexicanus) from Maryland and Georgia. Avian Diseases 40:335-341 
Luttrell MP, Stallknecht DE, Kleven SH, Kavanaugh DM, Corn JL, Fischer JR) Mycoplasma gallisepticum in house finches (Carpodacus mexicanus) and other wild birds associated with poultry production facilities. Avian Diseases 45:321-329

Luttrell MP, Fischer JR) Mycoplasmosis. In: Infectious Diseases of Wild Birds, Thomas J, Hunter DB, Atkinson CT (editors), Ames: Blackwell Publishing Professional, pp 317-331

Martinez-de la Puente J, Gustavo-Tomas SM, Moreno J, Morales J, Lobato E, García-Fraile S, Belda EJ) The blood parasite Haemoproteus reduces survival in a wild bird: a medication experiment. Biology Letters 6:663-665

Moguel P, Toledo M) Review: biodiversity conservation in traditional coffee systems of Mexico. Conservation Biology 13:11-21

Morishita TY, Aye PP, Ley EC, Harr BS) Survey of pathogens and blood parasites in free-living passerines. Avian Diseases 43:549-552

Norte AC, Araujo PM, Sampaio HL, Sousa JP, Ramos JA) Haematozoa infections in a Great Tit Parus major population in Central Portugal: relationships with breeding effort and health. Ibis 151:677-688

Nuttall GHF) Notes on ticks IV. Relating to the genus Ixodes and including a description of three new species and two new varieties. Parasitology 8:294-337

Perfecto I, Rice RA, Greenberg R, Van der Voort ME) Shade coffee: a disappearing refuge for biodiversity. Bioscience 46:598608

Perfecto I, Armbrecht I, Philpott SM, Dietsch T, Soto-Pinto L) Shaded coffee and the stability of rainforest margins in Latin America. In: The Stability of Tropical Rainforest Margins: Linking Ecological, Economic, and Social Constraints of Land Use and Conservation. Environmental Science Series, Tscharntke LT, Zeller M, Guhudja E, Bidin A (editors), Heidelberg: Springer, pp 227-264

Perfecto I, Vandermeer J) Biodiversity conservation in tropical agroecosystems: a new conservation paradigm. Annals of the New York Academy of Sciences 1134:173-200

Perfecto I, Vandermeer JH, Gustavo López Bautista GL, Nuñez GI, Greenberg R, Bichier P, Langridge S) Greater predation in shaded coffee farms: the role of resident neotropical birds. Ecology 85:2677-2681

Perozo F, Villegas P, Estevez C, Alvarado I, Purvis LB) Use of FTA (R) filter paper for the molecular detection of Newcastle disease virus. Avian Pathology 35:93-95

Peters VE, Greenberg R) Fruit supplementation affects birds but not arthropod predation by birds in Costa Rican agroforestry systems. Biotropica. doi:10.1111/j.1744-7429.2012.00891.x

Philpott SM, Armbrecht I) Biodiversity in tropical agroforests and the ecological role of ants and ant diversity in predatory function. Ecological Entomology 31:369-377
Philpott SM, Bichier P, Rice R, Greenberg R) Field-testing ecological and economic benefits of coffee certification programs. Conservation Biology 21:975-985

Proctor HC) Feather mites (Acari: Astigmata): ecology, behavior, and evolution. Annual Review of Entomology 48:185-209

Rappole JH, King DI, Vega Rivera JH) Coffee and conservation. Conservation Biology 17:334-336

Rice RA, Ward JR) Coffee, Conservation and Commerce in the Western Hemisphere, Smithsonian National Zoological Park: Washington, pp 1-40

Romagnano A) Examination and preventive medicine protocols in psittacines. The Veterinary Clinics of North America. Exotic Animal Practice 2:333-355

Roy P, Dhillon AS, Lauerman L, Shivaprasad HL) Detection of pigeon circovirus by polymerase chain reaction. Avian Diseases $47: 218-222$

Sanchez-Azofeifa GA, Pfaff A, Robalino JA, Boomhower JP) Costa Rica's payment for environmental services program: intention, implementation, and impact. Conservation Biology 21:11651173

Schnebel B, Dierschke V, Rautenschlein S, Ryll M) No detection of avian influenza A viruses of the subtypes $\mathrm{H} 5$ and $\mathrm{H} 7$ and isolation of lentogenic avian paramyxovirus serotype 1 in passerine birds during stopover in the year 2001 on the island Helgoland (North Sea). Deutsche Tierarztliche Wochenschrift 112:456-460

Sekercioglu CH, Loarie SR, Brenes FO, Ehrlich PR, Daily GC) Persistence of forest birds in the Costa Rican agricultural countryside. Conservation Biology 21:482-494

Stanislawek WL, Meers J, Wilks C, Horner GW, Morgan C, Alexander DJ) A survey for paramyxoviruses in caged birds, wild birds, and poultry in New Zealand. New Zealand Veterinary Journal 49:18-23

Stiles GF, Skutch AF) A Guide to the Birds of Costa Rica, Ithaca: Cornell University Press

Taylor M, Coop B, Wall R) The laboratory diagnosis of parasitism. In: Veterinary Parasitology, Taylor M, Coop B, Wall R (editors), Ames: Blackwell Publishing, pp 895-900

Wobeser GA) Disease in Wild Animals: Investigation and Management, Heidelberg: Springer

Yabsley MJ) Capillarid nematodes. In: Parasitic Diseases of Wild Birds, Atkinson CT, Thomas N, Hunter DB (editors), Ames: Wiley-Blackwell

Young BE, McDonald DB) Birds. In: Monteverde: Ecology and Conservation of a Tropical Cloud Forest, Nadkarni N, Wheelwright $\mathrm{N}$ (editors), New York: Oxford University Press, pp 179-222 